\title{
Policy Model for Managing State Owned Enterprise
}

\author{
Riant Nugroho \\ Senior Visiting Lecturer of Institute for Economic and Social Research, Faculty of \\ Economy and Business, University of Indonesia; Chairman of Institute for Policy \\ Reform - Email: riantnd@gmail.com
}

\begin{abstract}
State Owned Enterprises (SOEs) is a unique phenomenon of developing countries economy. Indonesia SOEs has come as a policy of MNC nationalisation post Independence. The policy then turn into savior of the nation's economy while in 1998/1999 crises. The next policy was turning the groups of industries into the profesionally managed corporation and become the leading national players in the global competition. The policy has been promoting by all administrations post reform, and the SOEs have a sound business performance. It raised the three questions for the next challenge: it is a need to keep the Ministry of SOEs, and how to make a perform policy on SOEs. The answer is, there is a t need o abolish the office. The second answer is there is a need to define the next mission of the SOEs. There are two critical new missions that need to be redrawn by policy makers. First, in the well-developed economy and liberalized market, SOEs act as "countervailing actor" toward market players rather than to dominate. Secondly, in the next 50 years, it is probable SOEs will be one of the principal contributors for state budget.
\end{abstract}

Keywords: public policy, state owned enterprises

\begin{abstract}
Abstrak
Badan Usaha Milik Negara (BUMN) adalah fenomena unik ekonomi negara berkembang. BUMN Indonesia telah datang sebagai kebijakan nasionalisasi MNC pasca Kemerdekaan. Kebijakan itu kemudian berubah menjadi penyelamat ekonomi negara sementara pada 1998/1999 krisis. Kebijakan selanjutnya adalah mengubah kelompok industri menjadi korporasi yang dikelola secara profesional dan menjadi pemain nasional terkemuka dalam kompetisi global. Kebijakan ini telah dipromosikan oleh semua administrasi pasca reformasi, dan BUMN memiliki kinerja bisnis yang baik. Ini mengangkat tiga pertanyaan untuk tantangan berikutnya: itu adalah kebutuhan untuk menjaga Kementerian BUMN, dan bagaimana membuat kebijakan kinerja pada BUMN. Jawabannya adalah, tidak perlu menghapuskan kantor. Jawaban kedua adalah ada kebutuhan untuk mendefinisikan misi BUMN berikutnya. Ada dua misi baru yang penting yang perlu digambar ulang oleh para pembuat kebijakan. Pertama, dalam ekonomi yang berkembang dengan baik dan pasar yang diliberalisasi, BUMN bertindak sebagai "aktor penyeimbang" terhadap para pelaku pasar alih-alih mendominasi. Kedua, dalam 50 tahun ke depan, besar kemungkinan BUMN akan menjadi salah satu kontributor utama anggaran negara.
\end{abstract}

Kata kunci: kebijakan publik, Badan Usaha Milik Negara 


\section{INTRODUCTION}

There are some critical new frontiers of public administration. Managing State Owned Enterprises (SOEs) -or Government Linked Corporations (GLCs)- is the next frontiers of public administration in Indonesia. There are three reasons: first, Indonesia's constitution states that $\mathrm{SOE}$ are acknowledged as one of the national economic actors -besides private and cooperative. Therefore, their presence is inevitable, even though it has been heavily criticized, both academically and practically. Second, Indonesia's SOEs are the economic deliverers in several economic crises -in 1970s, 1998, and 2008. Their contributions beyond business and financial milieu are indeed politically and socially. Thirdly, Indonesia is undergoing young demographic age; it means that there will be a greater amount of workers than pensioners; there will be also potency for productivity and therefore more taxpayer than tax-beneficiaries. In the future, there should be a new potential institutional tax-payers to government -as public administration's institution-as the demographic structure changes into an ageing one; whereas the population of the pensioners -as the tax-beneficiaries- will be much the same with the individual taxpayers; as the private sector will be more loyal to business opportunities than its political mother-land, meanwhile cooperatives will be preserved as small and weak business players.

Reframing the SOEs as one of the new frontiers of public administration especially when it means bureaucracy- has become an extraordinary premise since the active participation of SOEs in global economy has long been a topic of much debate. Following the wave of privatization in the United Kingdom (UK) from the early 1980s during the administration of Margaret Thatcher, a strong advocate of neoliberal policies who favored private over public enterprise, minimal state intervention was encouraged based on the belief that this would engender efficient employment of resources. Similar argument about the need of "small government" was also adopted and propagated subsequently in the United States (US) by Ronald Reagan, who was along with Thatcher, strongly argued that the state must dissociate itself from business.

In October 1995, the World Bank released policy research on State Owned Enterprises (SOEs) entitled Bureaucrats in Business: The Economics and Politics of Government Ownership ${ }^{\mathrm{i}}$. In its first paragraph, it is stated that:

"Bureaucrats are still in business. Despite more than a decade of divestiture efforts and the growing consensus that government perform less well than the private 
sector in a host activity, state-owned enterprises (SOEs) account for nearly as a large a share of developing economies today as twenty years ago" (World Bank, 1995, 1).

The main premise of the World Bank was "business is not the core mission of government, and therefore its core competence, hence government advisedly to leave the business of business. Business is not the core competence of bureaucracy; therefore, they should leave. The solution is government have a kind of 'company contracts' in which there are three types of company contracts: performance contracts between a government and a public manager, management contracts between a government and the private manager of a government firm, and regulatory contracts between a government and a privatized, regulated monopoly".

"Bureaucrats typically perform poorly in business not because they are incompetent (they aren't), but because they face contradictory goals and perverse incentives that can distract and discourage even very able and dedicated public servants. The problem is not the people but the system, not bureaucrats per se but the situation they find themselves in as bureaucrats in business" (World Bank, 1995, 3).

Those World Bank's words were mostly believed in Indonesia that day, especially among whom that called as "global economic advisors" -from global business consultant to IMF ${ }^{\mathrm{ii}}$. State Owned Enterprises were noting but an inefficient and red tape corporate. It was the same as bureaucracy in most developing countries. Therefore, the only solution was to sale -even in a "fire-sale"- all the SOEs by all means. Government divestiture was the most important policy.

Instead of following those advises Indonesian policy makers had different view about SOEs. They had to work for a "solution", and not a problem, to national economy. Indeed, books and premises that criticized market fundamentalism -from Stiglitz $(1999,2001)$ to Kaletsky (2010) -were not present at that time. But, to put SOEs as the economic drivers -rather than just did divestment- was a preferred policy.

However, in Indonesia, the idea of keeping government out of business, especially through SOEs, was being reconsidered even before the onset of the global financial crisis. This is because there were GLCs that had acquired a reputation for outstanding business performance, contributing extensively to the economies of their countries ${ }^{\mathrm{iii}}$. Indeed, many Indonesian SOEs had come to be seen as "best practices" companies, compared to those in the private sector. 
This suggests, particularly in the post global economic crisis period, that the core argument should not be whether neo-liberalism, including privatization, or state capitalism is the best way forward. Instead, the debate should focus on the most pragmatic approach to be adopted by government to ensure that GLCs perform better as business entities to promote economic growth in a country. This is crucial as GLCs continue to have a major presence in developing economies, contributing significantly to national economic development (Yescome 2006; Nugroho 1999; Nugroho \& Siahaan 2006; Nugroho \& Wrihatnolo 2008; Abeng 2002).

The idea of government's presence in the business through SOEs is another side of unwritten fact of the "4.0 Capitalism" of Anatole Kaletsky (2010). As the involvement of the government in business in the US in the post-crisis period -President Barrack Obama would later note that this was "inevitable"- was seen as imperative to rectify problems created by inadequately regulated financial enterprises and to construct an agenda that would help protect and consolidate the well-being of the domestic economy. US, as the most advanced liberal-capitalist country has been adopting the idea of “nationalizing private's assets" post 2007-2008 depression, as US Government took over corporate titans as General Motors (60 percent equity stake) and American Insurance Group (79,9 percent equity stake). Indeed, US did not mention as SOEs or GLCs (Government Linked-Corporation), but "Government Sponsored-Corporations" (GSCs). This was a historic moment, for when the US asserted the need for greater state intervention in the economy, governments around the world began to accept the need to employ SOEs far more effectively and productively.

Global financial crisis in 2008 has brought the world to the brink of economic collapse, a strong critique about neoliberalism emerged bringing to the fore debates about models of development, including the employment of SOEs to generate growth. The role of the state in the economy was now clearly fundamental, given the significant presence of SOEs in key sectors in both developed and developing countries. The Indonesia's experience hopefully provides a beneficial insight about how we comprehend SOEs today and tomorrow.

The objective of the research is to find the model of policy transition of SOEs post Soeharto Era (2000 - 2012) as a lesson learned for the policy makers on SOEs in the 
next periods. It has to be concerned, that the policy of SOEs in Indonesia has been changing as the Ministry has changed -and even when the President was change.

This research is a policy research, as its object is a set of policies on state owned enterprises of Indonesia from 2000-2019. As noted by Ann Majchrzak, policy research is a always a mixed-method model.

"In sum, policy research encompasses a number of different methods for undertaking the technical analysis.....an ideal policy research study is one that combines a number of different research methods..." $(1984,67)$.

In general, it is a qualitative research, as the method of analysi and verification is James Thomas, 2009). Focused synthesis research, which is a chosen library research approach that is interpreted critically by researchers. The method is carried out in the form of comparing the policy processes studied with the policy processes developed in public policy literature (Nugroho, 2012: 75). As noted by Majchrzak:

Focused synthesis is somewhat akin to traditional literature reviews by involving the selective review of written materials and existing research findings relevant to the particular research questions. However, focused synthesis differs from traditional literature reviews by discussing information obtained from variety of sources beyond published articles. For example, a typical synthesis might include discussions with expert and stakeholders, congressional hearings, anecdotal stories, personal past experience of the researchers, unpublished documents, staff memoranda, and published materials (1984: 59).

The researcher was working as team member to develop The Ministry of SOES (1997-1998), and was serving as special staff of the office 1997 - 1999. In 2000 - now the researcher serve as the Executive Director of the SOEs Exeucive Club, a foundation for monitoring the policy and performance of the Ministry of SOEs and its SOEs. Reseacher has been doing deep-interview with Miisters of SOEs, more than 200 Top Executives of the SOEs, and more than 20 economists from Indonesia, and about 12 high rank officers of the Office of the Ministry of SOEs. Researcher is conducting a comprehensive of strategic planning of each SOEs Ministers $(2000$ - 2012) to have a solid understanding about policy changing across periods.

\section{RESULTS AND DISCUSSION}

\section{Pre-Crises}

In Indonesia's 1945 national constitution, article 33 states that the most important national economic resources should be managed by the state. The "commanding height 
principle" is underpinning the idea of founding SOEs in Indonesia. It started in 1950s when the Indonesian government took over foreign corporations through nationalization process. Law 9/1969 on SOEs was grouping SOES into three models: Perjan (Bureau Corporations) which solely provide basic public services and non-for profit, Perum (General Corporations) which promoted public services and non for profit, and Persero (Limited Corporations) as a profit maker entity. All of those SOEs were managed under 17 Departments/Ministries in regard to its core business -i.e. Steel Industry SOE was managed under Ministry of Industry and Plantation SOE was managed under Ministry of Agriculture.

In 1983 the government released Government Regulation (or PP) No. 3 on Conduct on Managing SOEs that stated the ownership holder of SOEs was Ministry of Finance, and the policy of SOEs was Technical/Line Ministries. In 1990s, Indonesia had 182 SOEs and more than 1.000 of subsidiaries. Their businesses encompassed from plantation, mining, construction, banking, telecommunication, to airline. However, the business performance were unsound. The low performance of the BUMN business is not merely the fault of the management professionals, but because of the unfavorable organizational structure and existence (Nugroho \& Wrihatnolo, 2002).

In 1997, a year before crises, President Soeharto established the Ministry of the State Owned Enterprises (SOEs). It was a new post in the cabinet. The institution took over about 137 SOEs and about 1.000 of their subsidiaries from 17 Departmentsexcluded Pertamina, the oil and gas company that was still managed under Ministry of Mining and Energy.

The initial idea was not to make SOEs and economic generator, but as a way out to solve the government's debt that reached almost USD 60 billion. In a private discussion with Minister of Production and Distribution, Hartarto in 1997, President Soeharto noted that he would like to repay all the debt. In the discussion with Hartarto, I found that the plausible solution was by increasing the performance of the SOEs and therefore their market values. By selling less than 50 percent of some giant SOEs shares, it was possible that all the debt could be repaid and Soeharto might leave the Presidential post profoundly. Tanri Abeng, the Chairperson of Indonesia Management Association and President Director of Bakrie \& Brothers, was asked to develop a model 
for managing the SOEs. His proposal was accepted and he was later appointed as the Minister of the SOEs (Abeng, 2001))

\section{First Period: From Soeharto to Habibie, 1997-1999}

The Asian financial crises in 1997/1998 hit Indonesia economy severely compare to other countries such as South Korea, Thailand, Malaysia, and Singapore. In August 1997, IMF advised the Indonesia's administration to float the currency and to close 16 suspected unhealthy banks. The advice was taken fully; however, the floating currency policy and closing 16 national banks had led the country into an instant economic collapse. As Rupiah was crushing down from IDR 2,500 per USD to IDR 17.000 per USD in less than 9 months. As the closing of the banks had led a massive rush across the country that made banking system as the economic fuel was collapse, too. Indonesia PDB per capita was rushed out from USD 1,115 in 1996 to become USD 610 in 1998. 60 percent of population was becoming instantly poor. Total debt insurgence into USD 130 billion -half of them was private debt, therefore the premise that private sector was the economic generator was a mistake. But the most severe was the dying almost all of the business players, from banking to construction, from trade and tourism to technology, from service to manufacture.

On 21 May 1998 Soeharto resigned since the national instability was uprising as the impact of the Asian crises that turned out to national economic collapse. BJ Habibie, as Vice President, became President -according to Constitution. In the transition, the Office of the Ministry of SOEs was maintained, while Tanri Abeng retained his position as Minister. The idea of paying national debt through performed SOEs was changed into making SOEs and national economic locomotive to lead the national economic recovery, as SOEs had become the only "player in town". Abeng promoted the idea for performing SOEs through three sequential steps:

1. Retructurization. It means turning the in-efficient and less-efficient business corporation into the most efficient through changing the people, management structure, and their line of business. As the core strategy, Good Corporate Governance (GCG) was introduced as the new imperative for managing SOEs. The core and ultimate of restructuring is Holdingization, by meaning that the 128 of SOEs should be managed by 12 Super-Holding. The core idea is simple: it is easier to find 12 excellent world class CEOs instead of 128 ones. 
2. Profitization. It means that the sound restructuring program of the SOEs will lead into the profit making corporations instead of loss-making ones.

3. Privatization. It means inviting other parties to take over some shares of the SOEs as a method to leverage the management practices of the SOEs, include to increase its transparency, financial access, market penetration, and business expansion.

In 1998 Government of Indonesia released Regulation No. 12/1998 and No. 13/1998 that separated function of Ministry of Finance as government agency as owner of the SOEs, Ministry of SOEs as the operator, and line ministries as regulator. In this period, government released a conduct for implementing good corporate governance amongst SOEs. Alongside of releasing regulation, the Ministry of SOEs released the "1 1 st Wave SOEs Reform Masterplan". The masterplan noted that there were two missions of SOEs:

1. to develop the world class corporations. The idea derived from James Champy (1998) proposition that in the globalization, the actors who compete is not the nation states but the corporates of those nations. SOEs mission is to play role as national carrier's flag.

2. to become national economic locomotive to recover the national economy. There are two understanding of becoming "economic locomotive". First, its role was to generate the other business player - privates and cooperatives. Second, to pay the national debt -it was about USD100 billion- meanwhile national income was insufficient to repay the debt.

The master-plan led SOEs into a right track. In 1997-1998, SOEs performance was profound, as numbers of unsound companies were reduced from 62 companies in 1994 to become 18 companies in 1998. The policy in managing SOEs was performing macro -the number of sound SOEs was increased into 68 percent from 59,9 percent- as well as micro as the total revenue was increased from IDR 52.6 trillion to IDR 81.7 trillion -increased 55,2 percent. In December 1998 the Jakarta Stock Exchange was recovered, inflation was reduced, and IDR was recovered from IRD 17,000/dollar to IDR 7,000-8,000/USD. In 1999, SOEs worked as core player to recover the economy as it performance created a new economic trust to Indonesia. The most performing was the inflation rate that down to 2.01 percent in 1999 , compare to 11.10 percent in 1997 and 
77.63 percent in 1998. The economic performance was strongly supported by successful privatization of Cement Gresik, Indonesia Port II, Indonesia Port III, and Indonesia Telecom, and divestment of government's share in Indofood. The programs itself generated capital amount to USD 1,039.7 million.

There were some critical issues which solved such as restructuring National Electricity Company (PLN), Garuda Indonesia Airways, and merger among four giant state-banks -Bank Expor-Impor, Bank Dagang Negara, Bank Pembangunan Indonesia, and Bank Bumi Daya- to became Bank Mandiri. The core of reform was to transform SOEs from bureaucrat -and political, too- entities to become business entities. Before reform, SOEs need to pass 62 desks to process their business proposal. Under new management, it was cut to become 2 or 3 desk. Therefore, the World Bank premise that SOEs is a bureaucrat in business was not relevant anymore, as the issue is that no matter its ownership, as long as it treated as business entities and the business managed professionally by professional managers.

The second reform was to change the policy approach to SOEs from control by process -as a specific attribute of bureaucracy- to control by result. The approach had successfully motivated professional managers of SOEs; they became so enthusiastic to develop ideas and find the most innovative business process and product. In 1998, total profit of SOEs was IDR 17.6 trillion, increase about 107 percent compare to 1997, IDR 8.5 trillion. The market driven SOEs had left its social, political, and cultural consideration in developing business, and moved into business considerations alone. Garuda was a success story of SOE reform.

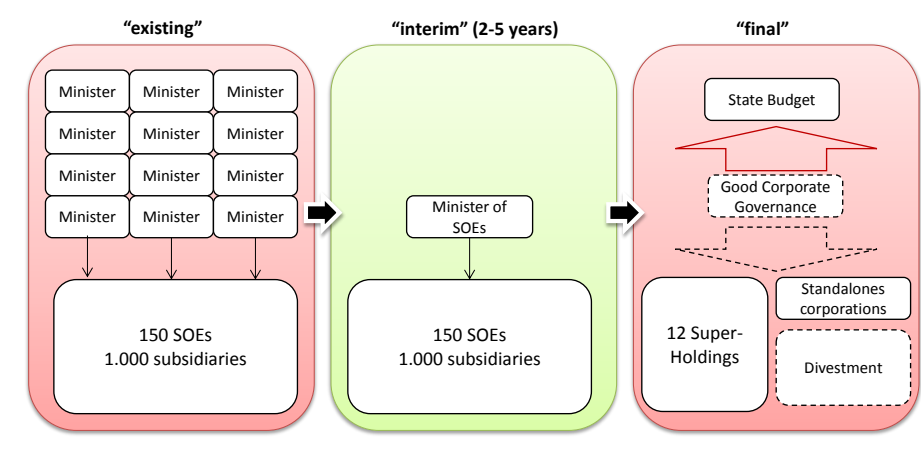

Figure 1. Transformation Plan

(Kementerian BUMN, 1999) 
The core contribution of Abeng was his concept " 2 nd Wave SOEs Reform Master plan" or named as "Master plan of SOEs Reform", that promoted the idea of business refocusing and regrouping also means that the Office of Ministry of SOEs should be temporarily as then replaced by 12 SOEs super-holdings of:

1. Financial

2. Energy

3. Agro industry

4. Airlines and Tourism

5. Strategic Industries

6. Telecommunication

7. Mining

8. Transport

9. Construction and Engineering

10. Pharmacy, Food, and Distribution

11. Forestry, Paper, and Printing

12. Post, Logistic, and Surveyor

The master plan successfully revaluates that if the reform is performing, there would be increasing of SOEs market value from USD 27.46 billion (exclude Pertamina and Berdikari) in 1999, to become USD 122 billion in 2005. Market value enhancement project then named as "value creation project" of SOEs (Kementerian BUMN, 1999). The vision of SOEs was to:

1. become world class companies

2. generating national economic

3. repay government's debt (Kementerian BUMN, 1999)

\section{Second Period: From Wahid to Megawati, 1999-2004}

Habibie was merely a transitory President. As he promised, in 1999 when there was a general election. Indonesian Democratic-Struggle Party (ISDP/PDI-P) won the election and became majority of People Consultative Assembly (PCA/MPR) by 153 seats, compare to prior ruling party Golkar, 120 seats, and National Awakening Party (NAP/PKB), 51 seats. Voting of the PCA (MPR) won Abdurrahman Wahid, senior leader and founder of NAP (PKB) as President, meanwhile Megawati, the Chairperson 
of IDSP (PDI-P) as second winner and elected as Vice President. In this conflictingcoalition government, the SOEs policy was ruling out.

Laksamana Sukardi, prior Managing Director of Lippo Bank (took over by CIMB Malaysia), senior leader of ISDP (PDI-P) posted as Minister of SOEs and Investment. SOEs issue was not become first priority of the government as the ministry also managed investment issue. Sukardi was a public figure with better imagery compared to Tanri Abeng. Sukardi involved more to the political issue than managing the SOEs, as he opened some of the corruption cases in some giant private enterprises which related to SOEs, for example the case of Texmaco and Bank BNI. Inside the office of SOEs, there were intense conflicts among political party's representatives -ie the Minister was from Party PDI-P, but the Secretary of the Minister was from Party of PKB; there were some Director Generals from PDI-P and others from Party of PKB, or other political parties. SOEs, again, became part of bureaucracy and politics. Professional managers were replaced by political and bureaucracy appointee. The success of reform in 1998/1999 under prior Ministry was over.

However, Sukardi promoted his interest on managing SOEs by developing his own idea. Tanri was developing three steps strategy of restructuring, profitizing, and privatizing. Laksamana, seemed to be obsessed about the SOEs stereotype, as private managers used to be, as a corrupt and unable to become a professionally managed corporation as long as it is owned by government. Therefore, he proposed two steps strategy, restructuring and privatizing. It was a fast track privatization model, as mostly advised by international financial adviser to Indonesia government (Rafick \& Amir, 2010; Djuraid, et,al., 2018; Nugroho \& Ricky Siahaan, eds, 2008; Kementerian SOE, 2018; Nugroho \& Wrihatnolo, 2002) ). However, Sukardi worked only for 7 months.

In April 2000, President Wahid reshuffled the cabinet. Sukardi was replaced by Rozy Munir, a senior economic lecturer of University of Indonesia, and also a leading member of Party PKB. Munir was about three months served as Minister. In August 2000 again President Wahid reshuffled the cabinet and the Ministry of SOEs was abolished. The management of SOEs was managed under Director General of SOEs, under the Ministry of Finance.

SOEs faced difficult time, as there were unclear and inconsistent policies toward state enterprises on one hand, and intense bureaucratic and political intervention that 
had abused business process on the other hand. In the same time, President Wahid was under-pressured for his inefficiency of managing the cabinet. Political crises were up healing at the first semester of 2001. However, SOEs performed well: dividend to the state budget increased 119 percent to become IDR 8.83 trillion -compare to the contribution in 2000. It proved that no matter political turbulence, SOEs worked as a business entity: to enhance market and create profit.

In July 2001, President Wahid was impeached by People Consultative Assembly. He was replaced by Vice President Megawati. Sukardi -as senior leader of PDI-P- was appointed as Minister of SOEs. Sukardi was then continuing his program. In April 2002 Sukardi promoted his master plan on managing SOEs 2002-2006. There were three phases: consolidation (2002), revitalization (2003-2004), and growth (2005-2006). In 2002, SOEs contributed as dividend to the state budget about IDR 9.76 trillion, and increased to become IDR 12.67 in 2003. In 2002, total contribution to the state budget amount to IDR 41 trillion, include dividend IDR 9.76 trillion, taxes IDR 23.5 trillion, and privatization IDR 7.7 trillion.

In the year of 2003, there were 128 from 158 SOEs that performed profoundly about 83.11 percent. The less were unsound. It was an improvement as compare to the year of 1999 when the numbers of performing SOEs were 75.73 percent. Sales were improved to become IDR 288 trillion from IDR 140.3 trillion in 1999. Profit increased from IDR 19.6 trillion (1999) to IDR 41.1 trillion (2003). Net profit increased from IDR 14.5 trillion (1999) to IDR 28 trillion (2003). Total asset increased from IDR 101.4 trillion (1999) to IDR 271.3 trillion. However, ROA was slightly improved from 2.39 percent (1999) to 2.81 percent (2003), meanwhile ROE was decreased from 14.36 percent (1999) to 10.34 percent (2003). This figure shows that the high political interfere was harmful to the SOEs performance -as we noted that in the period of 19992003 were intense political intrusion toward SOEs management.

Sukardi performance was more on privatization -as his core idea. In 2003-2004 there were 9 SOEs had privatized. They are Bank Mandiri, Indosat, Bank Rakyat Indonesia, Indocement, and PT Perusahaan Gas Negara, plus 5 SOEs on construction. Total revenue of privatization program was about IDR 9.9 trillion. The biggest privatization in his era was strategic selling of 41.94 percent shares of PT Indonesia 
Satellite to Singapore Technologies and Telemedia (STT). The decision was publicly criticized in which turned down the popularity of President Megawati.

In 2004, contribution of SOEs to the state budget decreased 22.6 percent to become 9.76 trillion. However, total contribution of SOEs to the state budget was increased from IDR 44.6 trillion (2003) to become IDR 52.30 trillion. The other contribution came from taxes IDR 39 trillion and privatization IDR 3.5 trillion.

In 2003, it was released Law No. 19/2003 on SOEs, the first policy on SOEs in Indonesia. The policy noted three important issues. First, that the SOEs was regrouped into two categories, Persero, it is a profit driven SOEs, and Perum, SOEs that has dual function, profit and social services. Second, SOEs defined by any corporation in which state has 51 percent shares or more. Third, the law stated that the Office of the Ministry of SOEs should be preserved. The third argument was an opposite toward the first idea of managing SOEs; in which the Office of the Ministry of SOEs was temporarily. The office shall be removed when the SOEs has been successfully transform into a professionally managed corporations and regrouped into about 12 holding companies.

The idea of managing SOEs was to remove the state corporations under ministerial bureaucracy extortion -it was 17 ministries that managed and squeezing SOEs. Presumably, the "extortion" is then concentrated in "one" ministry. The process to professionalize SOEs will depend more upon the integrity of the person who leads the ministry than the system.

In Sukardi era, government released Regulation No. 33/2005 on Method of Privatization. However, the method was more about political steps rather than business and operational steps -as it was promoted in 1998. The regulation stated that privatization annual program should be reported and agreed by parliament before executed.

\section{Third Period: SBY Part I, 2004-2009}

General (Ret) Yudhoyono won the direct presidential election in 2004. Yudhoyono was a leading military figure, ex Minister of Mining and Energy under President Wahid, and prior Coordinating Minister for Politics and Security under President Megawati. He was dismissed by President Megawati in 2003 after an intense conflict with President. He is the founder and Chairman of Democrat Party. Election in Indonesia in 2004 was unique, as it was the first direct presidential election in 
Indonesia's democracy. Besides, the other listed contestants were the most leading figure in Indonesia: Gen. (Ret). Wiranto, Megawati, Prof. Dr. Amien Rais, Gen. (Ret) Yudhoyono, and Hamzah Haz. Yudhoyono, who was in duet with Jusuf Kalla (as the Vice President), prior Coordinating Minister for Social Welfare, won the election.

Yudhoyono is not a new figure in regards with SOEs, as in 1999 he was appointed by Tanri Abeng, Minister of SOEs, to become the member of the Public Policy Committee in the Ministry of SOEs -the other member was Sultan Hamengkubuwono X (King of Yogjakarta), Prof. Bambang Sudibjo (then Minister of Finance), and Dr. Anwar Nasution (the next Governor of Central Bank)- therefore, he had a specific determination for SOEs.

Jusuf Kalla is a prominent businessman from South Sulawesi, and then leading Golkar Party, who dedicated his carrier to become government officer. Therefore, there was a lot of optimism that policy of SOEs would be back to the right track.

President SBY promoted Sugiharto, Chief Financial Officer of Medco Corporation, a leading oil and gas company owned by family of Arifin Panigoro. Sugiharto knew that there was a blueprint of managing SOEs in 1999 by Tanri Abeng. He presented the idea to the President, and it was in accordance.

Sugiharto then released Master Plan SOEs revitalization 2004-2009 in the SOEs Summit on 25 January 2005 (Rafick \& Amir, 2010; Djuraid, et,al., 2018; Nugroho \& Ricky Siahaan, eds, 2008; Kementerian SOE, 2018). There were three phases in managing SOEs: planning and fixing phase (2005-2006), restructuring and growth phase (2006-2007), and value creation phase (2008-2009). The master plan had been built by Tanri Abeng's 1999 SOEs Master Plan Reform, with the difference that Sugiharto was underpinning his strategy on financial engineering, as it was his core competence.

Sugiharto was working in the very supportive circumstances. He promoted a policy in regard of privatization that ratified by President as Government Regulation No. 33/2005 on Privatization. The policy was in accordance to the Law No. 17/2003 on State Finance and Law No. 19/2003 on SOEs. The main issue of the regulation was that government should prepare a privatization planning, then promoted to parliament, and after a parliamentary consultation, the program could be implemented without political interfere. 
Sugiharto was "somebody new" to the SOEs circumstances. He also took people that perceived as "new-comer". Therefore, the implementation of the strategy was strike with some difficulties. He could not execute his promise to replace Board of Director of 40 SOEs. He was facing a single difficulty: "a resistance to change", as he mentions in 2007. It was resistance among SOEs and among political patronages of the SOEs.

However, he tried as good as he could, to adopt his strategy to roll-up SOEs into holdings -holdings of Logistic, Mining, Plantation-- as the core concept of Tanri Abeng that Sugiharto would like to execute, was failed. He also faced some internal conflict inside the office.

In fact, Sugiharto was more concern on "developing" SOEs than "selling". He took profitization rather than privatization. In 2005, Sugiharto was asked by Coordinating Minister for Economics, Aburizal Bakrie -Chairman of Golkar, owner of Bakrie \& Brothers and Bumi Resources- to perform privatization with target IDR 3.5 trillion. Sugiharto preference was to increase SOEs business performance.

In 2006, there were 126 SOEs -from 138- that created profit of IDR 45.41 trillion. It was a good performance; actually, compared to 2005, there were 107 SOEs that created profit IDR 34.52 trillion. In 2006, total contribution of SOEs to the state budget was IDR 68 trillion; increase 23.7 percent compared to 2005.

Until mid-2006, there was no SOEs privatization program. For Sugiharto, it was nothing wrong, as he had two enfolded strategies: profitization and/or privatization. Instead of privatization, it could be profitization. He stated strongly that if any SOEs privatize it is because the business need to do so; it is not because the political calling, even from senior minister. In December 2006 Sugiharto privatized National Gas Company (PGN) and earned IDR 2.19 trillion.

In the first semester of 2007, Sugiharto promised to bring 18 SOEs to the privatization program. Some of them were Jasa Marga (toll road operator), Bank BNI, Wijaya Karya (construction), Permodalan Nasional Madani (finance), and Garuda Indonesia (airlines). Sugiharto had no time to execute his program.

In May 2007 President SBY reshuffled his cabinet. Sugiharto was replaced by Dr. Sofyan Djalil - previously he was Minister for Communication and Information. Djalil, senior lecturer of University of Indonesia, was Tanri Abeng's Deputy in 1998-1999. Djalil continued Tanri's and then Sugiharto's strategy in managing SOEs. 
Djalil returned to the original idea of managing SOEs: the Ministry of SOEs is a temporary one. "I hope I will be the last minister" (Rafick \& Amir, 2010; Djuraid, et,al., 2018; Nugroho \& Ricky Siahaan, eds, 2008; Kementerian SOE, 2018). There were three phases in managing SOEs: planning and fixing phase (2005-2006),. He was challenging the Law 19/2003 on SOEs, actually. He came with the concept of rightsizing. The target was that in 2007, from 139 SOEs would be reduced to 100 SOEs. The next year will be reduced into 50 SOEs, and so forth. Super holding was a vision that seems like to be achieved, as Djalil was one of Tanri team members.

Djalil was firmed with holding strategy as he knew that potency of SOEs was astonishing: in 2006 total asset was IDR 1,361 trillion, sales IDR 870 trillion, net profit IDR 54.4 trillion, and market capitalization at Jakarta Stock Exchange of 12 SOEs were IDR 493.2 trillion -about 40.23 percent from total market capitalization. As compared to Temasek (per 2007) total asset was equivalent to IDR 1,452 trillion, sales equivalent to IDR 444 trillion, and net profit equivalent to IDR 72 trillion.

To speed up his program, Djalil invited some senior managers from private sector as key consultants, such as Budi Setiadharma (ex CEO of Astra International) and Budi Pranoto (ex CEO Astra Otoparts). Djalil had two obsessions: to separate SOEs from politics and to conduct holdingization as fast as it can be. Privatization was the next step. Djalil performed good corporate governance, as his expertise, as the key method to execute his idea. He also invited senior managers from private sectors to join the senior management board of key SOEs, as such in Garuda Indonesia and National Gas Corporation.

Djalil formulated his program intro three phases strategy of managing SOEs: restructuring and consolidation (2006-2009), holdingization (2009-2014), and becoming regional and world-class corporations (2014-2019). Djalil had support from President by Presidential Instruction No. 5/2008 on SOEs restructuring. To protect SOEs from political intervention, Djalil released Ministerial Decree No. 15/2008 to prevent Board of Directors and Commissioners to be involved with any political activities.

The problem was: it was not easy to change the SOEs. Government might change the CEOs and management, but resistance was so high that make SOEs reform under Djalil was as uneasy as Sugiharto. However, Djalil was the Minister who revitalized the concept of "Holdingization" of SOEs; a core concept in managing SOEs. The idea of 
rolling-up SOEs faced the "living resistance" that made the process has not successfully implemented.

Despite the turbulence was, SOEs were still performing. In 2007, SOEs contribution to state budget about IDR 95.98 trillion: dividend IDR 23.22 trillion, taxes IDR 69.63 trillion and privatization IDR 3.13 trillion. In 2008, there was no privatization performed, but total contribution was increased to become IDR 125.48trillion as the contribution from dividend increase to become IDR 29.08 trillion and taxes IDR 91.55 trillion.

\section{Fourth Period: SBY Part II, 2009-2014}

The incumbent President SBY won his second term in 2009 election. He led the nation for the next 5 years (2009-2014). SBY turned his choice in managing SOEs to former Governor of Aceh (2005-2007) and previously President Director of National Food Logistic (Bulog) (2007-2009), Dr. Mustafa Abubakar (Rafick \& Amir, 2010; Djuraid, et,al., 2018; Nugroho \& Ricky Siahaan, eds, 2008; Kementerian SOE, 2018). There were three phases in managing SOEs: planning and fixing phase (2005-2006).

Abubakar generated two strategies: reforms the Office of the SOES and (then) reform the SOEs. Abubakar was continuing the Tanri's model, as exercised by Sugiharto and Djalil. Abubakar was rather a motivator than executing leader. He motivated SOEs to develop "Synergy among SOEs" as a pivotal step toward "holdingization". Abubakar has put a core concern of SOEs in Indonesia's Master plan for Fostering Economic Development (MP3IE). He acted as "Father" that encompassing the entire SOEs. He minds all the SOEs complaint and request for help and assistance. Therefore, he was popular among SOEs.

Abubakar introduced the new vision of SOEs as the vehicle to promote people welfare through their business with its value creation to the corporate social responsibilities (CSR). He wanted SOEs to be present in all important matters of the national economy.

The "soft approach" for managing SOEs had created a comfortable circumstance for SOEs. In 2009 SOEs performance hiked: total asset from IDR 1,977.80 trillion (2008) to become IDR 2,234.41 trillion (2009); net profit from IDR 78.47 trillion to IDR 88.05 trillion. However, total contribution to state budget decreased from IDR 125.48 trillion to become IDR 120.15 trillion. There was no privatization in 2009 , as 
Abubakar noted that privatization, especially through IPO, had to recognize three successful indicators: timing, sizing, and pricing. Abubakar was much inspired by China approach on managing SOEs.

In 2010 Abubakar seemed to be more confident to make next step to SOEs. He performed privatization of Krakatau Steel and Garuda Indonesia. Unfortunately, the IPOs were not successfully, as the secondary market responded negatively. Yet, privatization of Krakatau and Garuda contributed about IDR 2.1 trillion. Therefore, in 2010 SOEs increased their contribution to the state budget about IDR 137.41 trillion. In 2010, 17 of SOEs market capitalization in JSX were 26 percent; it was about IDR 819 trillion from IDR 3,100 trillion of total market caps. The biggest players were Telkom (IDR 161.2 trillion), Bank Mandiri (IDR 137.1 trillion), Bank BRI (IDR 129.4 trillion), Gas Negara (IDR 106 trillion), Bank BNI (IDR 71 trillion) Semen Gresik (IDR 56.6 trillion) and Bukit Asam (IDR 52 trillion).

Abubakar later faced a health problem. He was then replaced on 19 October 2011 by Dahlan Iskan (Rafick \& Amir, 2010; Djuraid, et,al., 2018; Nugroho \& Ricky Siahaan, eds, 2008; Kementerian SOE, 2018). There were three phases in managing SOEs: planning and fixing phase (2005-2006), formerly President Director of Indonesia National Electric Company (PLN). Iskan is a prominent business person. He was formerly Chairperson of Jawa Post Group, the second largest media conglomeration in Indonesia.

Iskan, as well as Abeng, is a prompt-to-action figure. Iskan's decision is to speedup the process of merger and acquisition of SOEs. The "in-pipe" decisions are rollingup SOEs to:

1. Holding of Agroindustry: merge and roll-up 15 SOEs with market value (before revaluation) about IDR 60 trillion

2. Acquisition about 10 of the least performing SOEs in machinery, film, publishing, survey, textile, energy, and construction.

Iskan is not a kind of "soft leader", as he noted that all the CEO and its Board of Directors has to deliver their promise to bring the value of the corporations. He even promotes the idea not to do "public service obligation (PSO) business" as used to be done by SOEs. PSO is a subsidy mechanism for SOEs that carry on the public services. 
Some of SOEs receive the PSO funds from state budget, i.e. railways and trains corporations, post office, electricity, fertilizer, to telecommunication.

Iskan led the way to keep the SOEs as leading in the economic development, include in the capital market. As noted per June 2011, market capitalization of 18 SOEs about IDR 866.46 trillion, 24.53 percent of Jakarta Stock Exchange total market capitalization $^{\text {iv }}$.

The SOEs contribution toward national budged has been up surging significantly; which considered as one of the principal contributor for national budget. In 2004, total SOEs contribution to the national budged was IDR 46.72 trillion. The figure was increasing in 2010 to become IDR 137.408 trillion; it is about 197.8 percent in six years. In 2011, Indonesia SOEs contributed IDR 115.6 trillion of corporate tax, IDR 28.1 trillion of dividend. Its asset reached IDR 3,422 trillion, IDR 1,495 trillion of sales, and IDR 145 trillion of net profit.

\section{Fifth Period: Jokowi Part I, 2014-2019}

Elected President 2014 - 2019 Joko Widodo (Jokowi) was appointing Rini Soemarno as Minister of SOEs. Former Presiden Director of national private conglomerate Astra International ${ }^{1}$, former Minister of Industry (2001 - 2004), and head of the Jokowi Transition Team (2014). She was not well-accepted by parliament since 2015. She was

banned from attending a meeting with the Council since the DPR plenary meeting in December 2015 when he received the recommendation of the Pelindo II Questionnaire Special Committee. At that time, the Special Committee recommended that President Joko Widodo dismiss Rini from the position of minister. The Committee assessed Rini and the Managing Director of PT Pelindo II R.J. Lino violated the constitution in the extension of the contract for managing PT Jakarta International Container Terminal between Pelindo II and Hutchison Port Holding (HPH). Since then, Rini's presence in meetings in parliament has been represented by the Minister of Finance ${ }^{2}$.

The management strategy is that the 143 SOEs must be managed professionally, transparently and capable of creating value and contributing to the country through increasing competitiveness and the role of SOEs in national development through the

\footnotetext{
${ }^{1}$ As of June 30, 2018, the majority of Astra's shares are owned by Jardine Cycle \& Carriage Ltd. Singapore, amounting to $50.11 \%$

${ }^{2}$ https://bisnis.tempo.co/read/1055365/rini-soemarno-diboikot-dpr-komisi-vi-kebingunganmengundangnya/full\&view=ok
}

Jurnal Academia Praja Volume 3 Nomor 2 - Agustus 2020 
power of economies of scale and holding and synergy. It is planned that an energy holding will be formed, in which PT Pertamina (Persero) will become a leader with total assets of around $\mathrm{Rp} 715.59$ trillion. The largest assets will be owned by financial SOE holding. The holding is led by PT Danareka (Persero) and consists of PT Bank Mandiri (Persero) Tbk (BMRI), PT Bank Rakyat Indonesia (Persero) Tbk (BBRI), PT Bank Negara Indonesia (Persero) Tbk (BBNI), PT Bank Tabungan Negara (Persero) Tbk (BBTN), PT Pegadaian (Persero), and PT Permodalan Nasional Madani (Persero). The total assets of the financial SOE holding are estimated to reach Rp 3,023.76 trillion.

While the holding of the SOE Karya, which will be led by PT Hutama Karya (Persero), will become a leader with members of PT Jasa Marga (Persero) Tbk (JSMR), PT Waskita Karya (Persero) Tbk (WSKT), PT Indra Karya (Persero), PT Wijaya Karya (Persero) Tbk (WIKA), PT Yodya Karya (Persero), and Trans Sumatra Operating Co. The SOE holding assets are estimated to reach Rp 154 trillion. Housing SOE holding, will be led by Perum Perumnas. While the members are PT Adhi Karya (Persero) Tbk (ADHI), PT PP (Persero) Tbk (PTPP), PT Virama Karya (Persero), PT Amarta Karya (Persero), and PT Indah Karya (Persero). The holding assets are estimated to be around IDR 42 trillion. The state-owned mining holding will be led by PT Indonesia Asahan Alumunium (Persero). Its members are PT Bukit Asam (Persero) Tbk (PTBA), PT Antam (Persero) Tbk (ANTM), PT Timah (Persero) Tbk (TINS), plus PT Freeport Indonesia. Later the mining SOE holding assets are estimated to reach Rp 182 trillion. SOE food holding, where Bulog Corporation will become a leader. Its members are PT Sang Hyang Seri (Persero), PT Pertani (Persero), PT Bhanda Ghara Reksa (Persero), PT Indonesian Trading Company (Persero), PT Perikanan Nusantara (Per sero), PT Perikanan Indonesia (Persero) and PT Berdikari ( Persero). ${ }^{3}$

Under Jokowi administration, SOEs profits record positive performance which is a tangible manifestation of the increasing role and competitiveness of SOEs as a pillar of economic development. In terms of assets, 143 state-owned companies have assets in 2014 of only Rp. 4,577 trillion. While in 2017 it rose to Rp 7.212 trillion. In 2018, assets became Rp. 7.817 trillion. In terms of equity, in 2014 it was still at Rp. 1,089 trillion. But in 2017 it shot to Rp. 2.387 trillion. Whereas in 2018 it is targeted to IDR

\footnotetext{
${ }^{3}$ see https://www.cnbcindonesia.com/news/20180126081829-4-2574/jokowi-dan-holdingisasi-SOE; http://www.neraca.co.id/article/111788/kinerja-SOE-dalam-4-tahun-kepemimpinan-jokowi-jk; https://finance.detik.com/berita-ekonomi-bisnis/d-4098798/rini-jelaskan-5-kunci-penting-pimpin-SOE; https://www.antaranews.com/berita/701013/rini-paparkan-strategi-memimpin-kementerian-SOE;
} 
2,563 trillion. At the income post, all SOEs in 2017 recorded IDR 2,208 trillion. While in 2014 the income was still at Rp. 1,955 trillion. In 2018, revenue rose to Rp 2,232 trillion so that this increase in income also supported SOE profits which amounted to Rp 186 trillion in 2017, up from the 2014 profit of Rp 148 trillion. The contribution of SOEs to development is seen from the continued increase in capital expenditure (capex) for development. In 2014, capital expenditure was only Rp 223 trillion, while in 2017 it was Rp 349 trillion consisting of Rp. 268 trillion for infrastructure and Rp. 81 trillion for non-infrastructure. In 2018, capital expenditure is set at $\mathrm{Rp} 563$ trillion. For contributions to the state budget, one of them is a state-owned enterprise that contributes from the tax side. For tax donations, in 2014 it amounted to Rp 178 trillion and in 2017 rose to $\mathrm{Rp} 211$ trillion, and in 2018 it will increase by $\mathrm{Rp} 217$ trillion $^{4}$.

It means that the SOEs have fulfilled its mission as principal state budget contributor, and this has been preserved as the national policy framework in managing SOEs. The premise of the excellence SOEs have to be proficient to create value for their stakeholders. The studies of SOEs in China (Cheong Kee-Cheok, at all, 2012), Japan (Suzuki, 2012), South Korea (Jong Gook Back, 2012), and South Africa (Mondi and Bardien, 2012) had verified the seminal premise.

\section{Managing SOEs as Key Policy Frontiers of Public Administration}

Indonesia's Public administration has been undergoing tremendous change since reformation. Indeed, the idea of privatizing government was induced by IMF in 1998, but from Habibie Administration to Yudhoyono Administration, the idea was taken partially. The main idea of the Indonesia's public administration is about how to save the economic condition of the nation. The idea of state capitalism that has been removed

\footnotetext{
${ }^{4}$ However, the SOEs have significat ammount of corporate debt. The Ministry of SOE's presentation in a meeting with the House of Representatives Commission VI, at the Parliament Building, Senayan, Jakarta, Monday (3/12/2018) shows that until the end of September 2018 Transportation SOE had a debt to equity ratio (DER) 1.59 times, while similar industries 1,96 times. SOE property and construction have DER 1.03 times, while similar industries are 2.99 times. Energy SOEs have DER of 0.71 times, while similar industries are 1.12 times. Telecommunication SOE has DER of 0.77 times, while similar industries are 1.19 times. Banking SOEs have DER 6 times, while similar industries have 5.66 times. The total SOE debt reaches $R p .5,271$ trillion. Of this amount, $R$ p. 3.311 trillion was contributed by financial sector SOEs, with the largest component being banking third party funds that reached $74 \%$ of total debt. Aside from deposits, state-owned debt in the financial sector was contributed by premium reserves, and accumulated pension contributions of Rp 335 trillion (10\%). Of these materials, Rp. 1,960 trillion of SOE debt came from the nonfinancial sector. The details are the electricity sector of Rp. 543 trillion or $28 \%$ of the total debt of nonfinancial SOEs. Then the state-owned oil and gas sector amounted to Rp 522 trillion $(27 \%)$, the property and construction sector Rp 317 trillion (15\%), the telecommunications sector Rp 99 trillion (5\%), the transportation sector Rp 75 trillion (4\%), and other sectors IDR 403 trillion (20\%). The number of SOE debts has increased. From the data from the Ministry of SOE, state-owned debt in 2016 was IDR 4,240 trillion, then IDR 4,830 trillion in 2017, and IDR 5,271 trillion in September 2018. The increase in debt was in line with the increase in assets and equity of SOE.
} 
since mid of 1980s by Thatcher and Reagan, remains in central idea of the Indonesia public administration. It is promoted as the frontiers of the administration's policy.

It is indeed in accordance to Ian Bremmer (2010) who notes that state capitalism is not a single coherent political ideology.

"It's a set of principles that government can adapt to meets its particular needs. State capitalism was growing before the market meltdown of 2008, but the financial crises and global recession have made it much more difficult for those who believe in free-market capitalism to make their case to those who don't.... State capitalism may not be with us forever, but it's likely to be around for decades to come" (Bremer, 2010: 23-24).

The policy decision of the Administration that leads to the rising of the state capitalism is somehow correct. In 2004-2008, 117 state-owned and public companies from Brazil, Russia, India, and China -the BRIC- appeared for the first time on the Forbes Global 200 list of the world larges companies, measured by sales, profits, assets, and market value (Bremen, 2010: 20).

Public administration in Indonesia has been working at the frontier at the administration's idea as the dominant ideology from 1980s until 2007-2009 crises assumed that market is always right and government is nearly always wrong (Kaletsky, 2010: 5). However, Indonesia's public administration policy on State-Owned Enterprises in-line with the changing nature of capitalism: from capitalism 3.0 to 4.0. As Kaletsky notes that the recent capitalism will no longer be based on the idea of marketfundamentalism and minimizing of the role of the government in economy.

"The emerging worldview of Capitalism 4.0 will need to recognize that the world is too complex and uncertain to be understood, let alone managed, by a naive reliance on markets, as in the last version of capitalism, or by excessive faith in benign and omniscient government, as in the model before... Capitalism 4.0 experts who claim to divine the future according to immutable economic laws are likely to be dismissed as charlatans, because the one thing we will know for certain about economics and public policy is that nothing is certain"(Kaletsky, 2010: 8-10).

Indonesian experience shows that SOEs is not merely part of bureaucracy and politics, but part of the nation's economic survival. In the 1998 crises, SOEs had become the only players in town. No one could imagine private sectors that so called as the future of the economy were collapse and brought the nation into instant bankruptcy.

The issue of SOEs is not about ownership, as noted by The World Bank (1995), but about the excellence of its management. Therefore, the core policy agenda for 
managing SOEs in the developing countries is: how to transform the SOEs from bureaucracy and political entity to become business entity, regardless the ownership government majority or minority. Indeed, the solution is not as easy on the paper. Managing SOEs in the developing countries means managing in the political turbulence. There is always political interest to take over SOEs.

Therefore, managing SOEs is not an extraordinary one. The extraordinary is the political turbulence that makes any excellent strategy was merely on paper. The original core strategy in managing SOEs in Indonesia was RPP: Restructuring, Profit, and Privatization. The main idea is to turn SOEs from political and bureaucratic entities to become the real business player. The model developed in 1998 and become one of the best models that being copied around developing countries.

Indonesia's problem is that the Presidents of Indonesia in 1999-today are hesitate to pick up the right direction to manage SOEs. The hesitation uncovers in selecting Minister of SOEs to selecting the macro policy in managing SOEs. Developing a permanent ministry of SOEs is inappropriate in regard to the vision transforming SOEs to become "real business player". How efficient the Office of SOEs is, it is still bureaucracy.

Indeed, politics and bureaucracy are not somehow harmful for SOEs. But, as their core mission -and therefore their core interest- is not for business. How excellent and professional they are, their presence as the determining actors is not a good choice.

The professional politicians and bureaucrats want to protect and preserve SOEs as business player by giving them the "Law of SOEs". Actually, the law is merely legitimizing the continuing unlimited intervention toward the SOEs. The most intervention is by the presence of the Ministry of SOEs.

Management of SOEs needs to be the same as private business. They have to go to the market and serve the people through efficient market competition and mechanism rather than depend upon protection from bureaucracy. Therefore, the continuous presence of the office of SOEs would be dubious. Managing SOEs under ministry is somehow the same with to tight the hand and legs of the SOEs while we want them to run fast.

This issue regards to the conceptually noted as "reorientation". It means that the policy maker has to redefine their understanding and therefore their idea about SOEs. It 
is as simple as switching from framework thinking that "SOEs is part of me" to become "SOEs is part of the nation". Identifying "nation" as "me" means that the politics or personalization, as demonstrated by authoritarian regime. They who prove themselves as the unadapt institution.

Reorientation will lead toward Restructuring, the next step. There is macro restructuring, in term of the appropriate policy for SOEs, include separating them into SOEs of:

1. profit making SOEs, i.e. banking to plantation

2. public service and non for profit making SOEs, i.e. public transport, water, and sewerage

3. monopoly SOEs, i.e. fertilizer, electricity, defense industry

4. investment SOEs, i.e. specific public infrastructure

The second macro restructuring is pushing the corporations to merge into several holding companies to make them easier to manage and watch. Holdingization is the consequence of the second macro-restructuring. It should be macro, by government's means; as SOEs need to have a strict way to be rolled-up to leverage its level of business efficiency.

There is micro restructuring, in the corporate level. It turns into injecting business efficiency, corporate competiveness, market acquisition, to the business redefinition. It is all the way to the profitization. How to make SOEs as business entity able to create value; and the business value is meaning market and innovation in which profit is the indicator of its business relevancy.

The next agenda is about how to change or transform SOEs successfully. The answer is depending upon their leaders. SOEs transformation is not a minor effort; it is a major one, if we could not spell "a big one". Corporations which stay alongside with monopoly, protection, and any other non-need-to-explain-facilities need to be led by a change leader. A leader who has three basic ingredients: vision, values, and courage. The success of transforming Garuda Indonesia and merger of four state banks into Bank Mandiri -now a leading bank in Indonesia- because of the strong-change-leader CEO Robby Djohan. The problem is always to find right people. Most of the corporations in the world have been facing the same problem: to find the excellent leader; the changeleader ones; moreover, for the developing countries. There is no guarantee that 
expatriate will be much better than local managers, as the most problem is not managing internationally, but how to move people in the local factory and plantations to become the efficient ones.

This stage would be better identified as "professionalization" of SOEs. It means injecting the real professional inside the CEOs. It has to be started from the top leader. It has to be the professional leader. They who become CEOs Chairperson because they are the selected professional people; it is not because they have some special relationship with the center of political power. The success of Garuda Indonesia and Bank Mandiri under Robby Djohan, and Indonesia's Electric Company (PLN) under Dahlan Iskan, are the most prominent experience in Indonesia. They are people who have willingness to have respectable corporations. Djohan was "buldozering" the unchanged people and system in Garuda and Bank Mandiri without fear of being fired by the Minister. Sometimes, he broke the rule. The culture discipline and integrity were the core strengths of Djohan. It was the same with Dahlan Iskan while he reinvented PLN before appealed as Minister of SOEs. He just committed to his promise: to make PLN perform soundly.

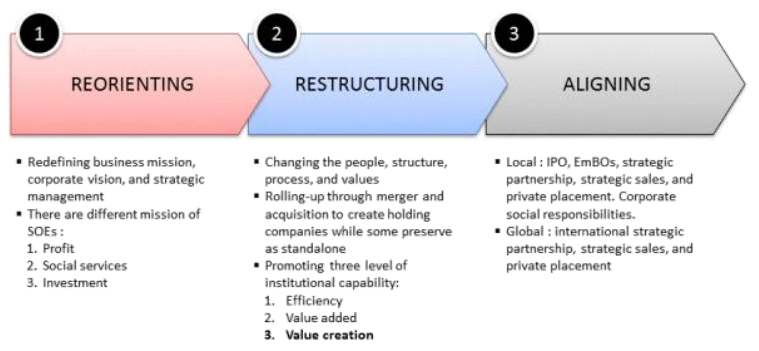

Figure 2. The Reform Method (Nugroho, 2008)

The last stage is aligning. Align is the basic of synergy. Synergy is the strongest energy today and tomorrow. SOEs have to align with national strategy, people as their stakeholders and customers, and market. It means the SOEs have to become open corporation by its presence in the national and global market, as they have domestic and global align, i.e. by strategic partners or strategic sales program, and presence in the stock market as the indicators of transparent corporation in one side, and at the other side to prevent SOEs from over-intervention-action of politics and bureaucracy (The World Bank, 1995), as they have the other shareholders that have the same right to say "no" to that unwise behavior. 


\section{CONCLUSION}

SOEs post Soeharto is becoming the performing economic players. Since Habibie to Jokowi Administration, there were an increasing business and economic contribution. There are the same strategies among Ministries: professionalism, competitiveness, and aim to become global players. Tanri Abeng was the first minister who promotes the strategy of restructuring, holding, and privatization as the basi methods to achive the goal. The next ministers were continuing and do some technical improvement. It means that there is no other methods to make SOEs become professionally managed therefore leverage as a competitive one and become world class player. The strategy has been implemented since 1998 to now. Therefore, whoever tha President and Minsters, the SOEs stays perform. It raises a question: is there is a need to keep the Office of the Ministry of SOEs? The first scenario if SOEs that the policy of managing SOEs is started by founding the Ministry of SOEs, and then transform into an Agency, and then it turns into the 10-12 Superholdings, meawhile the steps takes $3-5$ years (Abeng, 2001, Nugroho, 2008). The presence of the Law 19/2003 on SOEs has made the bureacucracy's administration unremovable. Therefore, the plan to revise of Law 19/2003 might be change into the abolishment of the bureaucratic office of SOEs. The presence of the office would keep political and bureaucratic over-interventions that make SOEs to become a bureaucratic and political institution rather than a professional entitiy (World Bank, 1995).

The second question is how a perform policy regard to SOEs? Managing SOEs is the next frontiers of public administration in Indonesia; constitutionally, economically, and financially. Over periods of development and economic crises -even the disastrous ones- SOEs has proven as nation's redeemer. Political turbulences have small impact for SOEs performance. Business performances of the SOEs depend more upon the quality of the management and their managers. It was found that the strategy of "professionalizing" of SOEs is more essential than "privatizing". The key success factor is about how to find leaders with ingenuity, discipline, and integrity, and practicing Good Corporate Governance, especially the value of transparency and accountability.

The next challenge is how to define the next mission of the SOEs. There are two critical new missions that need to be redrawn by policy makers. First, in the welldeveloped economy and liberalized market, SOEs act as "countervailing actor" toward 
market players rather than to dominate. Hence, the policy framework is changing, from agent of development to the countervailing actor in the imperfect market -as it always be, as the asymmetrical information will be the key of profit and, however, market imperfectness. It will be perhaps the new essence of the "Capitalism 4.0" that initiated by Kaltesky (2010). The dichotomy beliefs of "government (SOEs)" and "private" is not relevant anymore, as more and more SOEs are performing rather than private.

In the next 50 years, it is probable SOEs will be one of the principal contributors for state budget, especially for countries where SOEs are present as one of the major economic players like Indonesia; as in the future tax policy and government bond will become complicated and ambiguous policy options. Managing SOEs will, however, become a new frontier's agenda for public administration in the developing countries. However, policy of making SOEs performs should not in the "zero sum game" model, as private sectors would be suffer. And it is the next challenge of Jokowi, as the elected 2019 - 2024 Indonesia President as well as his/her top officers in managing the SOEs.

\section{REFERENCES}

Abeng, T. (2001). Indonesia Inc.: Privatizing state-owned enterprises. Singapore: Times Academic Press.

Anoraga, P. (1995). BUMN, swasta, dan koperasi: Tiga pelaku ekonomi. Jakarta: Pustaka Jaya.

Ascher, K. (1987). The politics of privatization-contracting out public services. New York: St Martin's Press.

Austin, J.M., Wortzel, L.H., and Coburn, J.F. (1986). Privatizing state owned enterprises: Hopes and realities. Colombia Journal of World Business, 21(3), 5160 .

Aylen, J. (1987). Privatization in developing countries. Lloyds Bank Review, 163, 15-30.

Back, J.G. (2012). Korean GLCs as the agent of national development. Paper presented at Conference on The State's Return to Business, Siem Riap, Cambodia, Feb. 9$10,2012$.

Bailey, R.W. (1987). Uses and misuses of privatization, in Steve H. Hanke (Ed.) Prospects for privatization. New York: The Academy of Political Science.

Barnett-Page and Thomas, J. (2009). Methods for the synthesis of qualitative research: A critical review. BMC Medical Research Methodology, 9(59), 1-11. 
Bastian, I. (2002). Privatisasi di Indonesia. Jakarta: Salemba Empat.

Beesley, M.E., 1997, ed., Privatization and Deregulation, London: Routledge.

Beresford, Q. (2000). Governments, markets, and globalization. Sydney: Allen \& Unwin.

Bos, D. (1985), A theory of the privatization of public enterprises. Journal of Economics, Supplement, 5, 17-40.

Bremmer, I. (2010). The end of the free market: Who wins the war between states and corporations?. New York: Portfolio.

Bridge, G. (1977). Citizen choice in public services: Voucher system, in E.S. Savas (Ed.). Alternatives for delivering public services -toward improved performance, Colorado, Westview Press.

Buchanan, J.M. (1972). The economics of earmarked Taxes, in J.M. Buchanan and Robert D. Tollison (Eds.). Theory of public choice I, Ann Harbor, University of Michigan Press.

Cheong Kee-Cheok, Li, R., and Zhang, M. (2012). China's state enterprises and global crises. Paper presented at Conference on The State's Return to Business, Siem Riap, Cambodia, Feb. 9-10, 2012.

Danim, S. (2005). Pengantar studi pemelitian kebijakan. Jakarta: Bina Aksara.

Djuraid, Hadi Mustofa, et,al., 2018, Leaders Behind SOEs: Kiprah dan Kebijakan Para Menteri SOE, Jakarta: Balai Pustaka;

Gwartney, J.D., \& Stroup, R.L. 1990, Economics: Private and public choice, San Diego: Harcourt.

Hanke, S. (1987). Privatization and development. California: ICS.

Kent, C.A. (Ed.). (1987). Entrepreneurship and the privatizing of government. London, Quorum Books.

Kaletsky, A. (2010). Capitalism 4.0: the birth of a new economy. New York: Bloomsbury.

Kolderie, T. (1986). The two different concept of privatization. Public Administration Review, 46(4), 285-291. 
Kusumoyoso, B. (2000). Menguatnya peran ekonomi negara: Nasionalisasi perusahaanperusahaan Belanda di Indonesia 1957-1959. Tesis. Fakultas Ekonomi, Universitas Gadjah Mada.

Majchrzak, A. (1984). Methods for policy research. London: Sage.

Minister of State Owned Enterprises/McKinsey, Booz-Allen \& Hamiltin, AT Kearney, PWC, E\&Y, 1999, Second Wave State Owned Enterprises Reform Blueprint: Creating of Highly Competitive and Value Creating Indonesia Enterprises, Jakarta: Minister of State Owned Enterprises

Mondi, L. \& Bardien, G. (2012). The changing role of a development finance institution in light of the financial crisis: the case of the Industrial Development Corporations conditional distress funding facility. Paper presented at Conference on The State's Return to Business, Siem Riap, Cambodia, Feb. 9-10, 2012.

Narain, L. (2003). Public enterprise management and privatization. New Delhi: S. Cand \& Company.

Nugroho, R. (1999). Indonesia state owned enterprises: Professionalism to go global. Jakarta: RBI Research.

Nugroho, Riant, \& Ricky Siahaan, eds, 2008, BUMN Indonesia: Isu, Kebijakan, dan Strategi, Jakarta: Elex/Gramedia;

Nugroho, Riant, \& Randy Wrihatnolo, 2002, "Pengalaman Revitalisasi BUMN", Majalah Bappenas, Edisi 27 Tahun 2002.

Nugroho, Riant, 2008, "Reformasi SOE", dalam Nugroho \& Siahaan, eds, 2008, SOEIndonesia: Isu, Kebijakan, dan Strategi, Jakarta: Elex/Gramedia

Nugroho, R. \& Wrihatnolo, R.R. (2008). Manajemen privatisasi SOE. Jakarta: Gramedia.

Nugroho, R. (2009). Public policy. Jakarta: Elex Media Komputindo/Gramedia.

Nugroho, R. (2012). Metode penelitian kebijakan. Yogjakarta: Pustaka Pelajar.

OECD Observer. (1986). Deregulation and privatization. OECD Observer No. 132, pp 14-17.

Pera, A. (1989). Deregulation and privatization in an economy-wide context, in OEDC Economic Studies No. 12.

Rafick, Ishack, \& Baso Amir, 2010, BUMN Expose: Menguak Pengelolaan Aset Negara Senilai $R p 2.000$ trilyun, Jakarta: Ufuk;

Savas, E.S. (1987). Privatization: The key to better government. New Jersey: Chatham House Publishers Inc. 
Shirley, M. (1988). The experience with privatization. Finance and Development, pp 34-35.

Stiglitz, J.E. (1988). Economics of the public sector. New York: W.W. Northon.

Suleiman, E.N. and Waterburry, J. (eds.). (1990). The political economy of public sector reform and privatization, Colorado: West View.

Suzuki, A. (2012). Changing role of the development Bank of Japan: From investor to key industries to provider of safety net. Paper presented at Conference on The State's Return to Business, Siem Riap, Cambodia, Feb. 9-10, 2012.

Vickers, J. \& Yarrow, G. (1988). Privatization-An economic analysis-. Cambridge: The MIT Press.

World Bank. (1995). Bureaucrats in business: The economics and politics of government ownership. Oxford: Oxford University Press. 